\title{
Many beginnings: the thought, thinkers and actions behind the planet-oriented architecture
}

\author{
Adrian Krężlik \\ Faculty of Architecture; University of Porto; \\ Via Panorâmica Edgar Cardoso 215, 4150-564 Porto, Portugal; \\ adrian.krezlik@gmail.com (iD)0000-0003-3200-8851
}

\begin{abstract}
The article maps multiple planet-oriented movements in the history of modern (predominantly western) architecture. It looks for architectural pronunciation of social movements, political actions and historical moments. In writings of acclaimed architects and authors, it searches for origins of organic, vernacular and tropical architecture and their offspring in the contemporary approaches, views and design. The article documents changes of perception of relation between man, nature and architecture. It commences with the very first attempts to understand this relationship: idealization and romanticisation of nature, it finishes with the most contemporary analyses based on the holistic approach and computer simulation. The article draws an extensive panorama of authors and publications that researched planted-oriented architecture.
\end{abstract}

Keywords: modern architecture; organic architecture; regenerative architecture; vernacular architecture; tropical architecture

\section{Introduction}

The article browses through the history of modern architecture to look for movements that led to planet-oriented architecture. An environmentally-sensitive approach that puts the care for the Planet and Nature as the centre axis of the design agenda. The planet-oriented architecture roots in a holistic approach and the systems theory, where all the elements are interrelated and interdependent. The article looks to organize scattered ideas to have a clearer overview on the topics that have been already researched by scholars in modern history. It helps to revisit the ideas from the past to nourish the planet-oriented research and to explain the origins of the movements.

The text is divided in four parts. The introduction maps the history of environmental movements and is aimed to provide a wider perspective, pointing out the most important events and texts. It serves as a reference point to the next four parts on organic, vernacular, tropical and bioclimatic, and planet-oriented architecture. The sections are organized around 
keywords and map the movements to explain the historical and contemporary frameworks that defined relations between architecture and the Planet.

The article is based on literature search around keywords: organic, vernacular, sustainable, green, restorative, regenerative, planet-oriented, tropical, bioclimatic; works of widely acclaimed architects and researchers; existing text on history of modern architecture - Modern Architecture by Kenneth Frampton and Modern Movement in Architecture by Charles Jencks; and a seminar on the history of modern architecture by Professor Gonçalo Furtado Lopes at the Faculty of Architecture of the University of Porto. The selected examples focus on the western authors of the $20^{\text {th }}$ century, both practitioners and theoreticians. Furthermore, the article tries to find a more egalitarian perspective and revisits the modern movements looking for texts written by women.

\section{Historical background}

The movements which have shaped planet-oriented design have appeared every now and then, every fifteen years, every decade, every generation. John Ruskin's writings could be used as one starting point to understand and map modern critique on the relation of nature with a human. Ruskin, an English writer and critic, had a great impact on the way that nature has been understood among early $20^{\text {th }}$ century society. Though, his vision of nature, or as he would write Nature [1], to underline the admiration and respect to nature, was, at least from today's point of view, romantic and idealizing. Many of his thoughts could be found in The

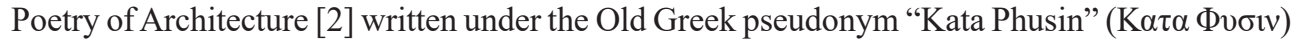
which means 'according to nature, living by nature'. As John Dixon Hunt summarizes Ruskin's views 'the problems, [...], were not with nature itself but with the human treatment of it' [3]. It could also be Emily Brontë in Wuthering Heights who outlined the relation of inhabiting in relation to nature. Their artistic activity coincides with the time of rapid industrialization, urbanization, and, on the opposite pole, the environmental movement has been very active in public and political spheres. It led to establishing the first National Park, Yellowstone (USA), in 1872. At this point, the discussion on the protection and conservation of natural heritage was quite vivid. This movement should be probably considered the most efficient and effective in terms of environmental protection.

At the beginning of the century, a rapid industrialization brought severe air pollution to the cities. In 1905 Henry Antoine Des Voeux coined the term smog [4] that had commenced more profound discussion and research in that topic. In 1908 the National Conservation Commission was appointed in the United States of America. In the twenties and thirties there were some minor movements such as the funding of Izaak Walton League (1922), Convention Relative to the Preservation of Fauna and Flora in their Natural State in the USA (1933) or the publication of Game Management [5] on wildlife conservation. The Nazi Germany already in the 1930 has introduced numerous environmental protection policies [6] including the ban on vivisection and cruelty towards animals, and several restrictions on hunting. The intention was not as pristine as the actions could suggest - it was all part of a larger agenda of national identity building rooted in the romantic vision of man's relationship with nature.

The years of the world wars and armed races at the beginning of the $20^{\text {th }}$ century destroyed the planet in an unprecedented way. The topic of the protection of nature was not a priority. It wasn't until the 1960s that Rachel Carson, an American environmentalist and author, wrote Silent Spring [7], a book about insecticides and their impact on biodiversity. But it was not a text purely about insecticides, it was about the industrialization impact on natural landscapes 
and the capitalization of resources in the name of growth and prosperity. The publication is widely considered as a new chapter in the environmental protection movement. As a result, the US government banned the use of chemicals based on high DDT concentration from agriculture. The First Earth Day was organized on April 22, 1970, a year later Greenpeace was formed. In 1972, the Roman Club Report indicated the limits of planet growth and the risk of crossing them, confirming that the actual pace of growth is simply unsustainable and would lead to resource depletion. Though it was the Oil Crisis which commenced in 1973 that influenced the industries attitude towards nature, fused the previously dispersed environmental movements and allowed them to grow in strength [8]. The embargo targeted towards the most developed and industrialized countries such as Canada, Japan, the Netherlands, the United Kingdom and the United States alternated the development of their economy [9] and modern architecture, as its derivatives.

The future and the danger of planet destruction were discussed in particular at the turn of the eighties and nineties. In 1987, the Brundtland Commission Report - Our Common Future came out, which introduced to the common language the phrase 'sustainable development':

Sustainable development is a development that meets the needs of the present without compromising the ability of future generations to meet their own needs [10].

In 1988 the IPCC (Intergovernmental Panel on Climate Change) was created. In the same year, James Hansen, head of the Goddard Institute for Space Studies at NASA testified to the American Congress that he is $99 \%$ convinced that it is mankind who is responsible for climate change [11]. In 1989 Time Magazine deviated from the 'Man of the Year' formula in favour of 'Planet of the Year': Endangered Earth. In 1991 a declaration on biodiversity was signed in Rio de Janeiro. In 1997 the Kyoto Protocol was signed, in 2015 the United Nations General Assembly set the 17 Sustainable Development Goals (SDG) to be achieved by 2030 as 'a blueprint to achieve a better and more sustainable future for all'. A year later in Paris most of the countries agreed to keep the global warming level below 2 Celsius degrees. Finally, in 2017 global environmental activity was hitting back. The latest IPCC Report indicated that radical and widespread initiative must be undertaken to avoid a severe crisis. All the mentioned events triggered certain architectural movements and approaches in modern history, shaping diverse solutions and attitudes, each time more informed and conscious.

There have been multiple beginnings of sustainable design, triggered by different political and social movements or events. There is some continuity and common denominators between them. Unfortunately, the planet-centred design has had many beginnings and many endings, each time focusing on a different aspect. The following paragraphs will attempt to organize the knowledge and practice around the following topics: organic, vernacular, planet-oriented, performance-oriented, bioclimatic, and regenerative.

\section{Mapping architecture through publications}

The idea of sustainability, green, planet-oriented architecture has evolved, changed its names, scientific bases, frameworks, and forms of expression throughout the years. As already mentioned, the word 'sustainable' in the context of development could be found only in the late ' 80 s. Different definitions have been used to talk about relation nature - architecture man. Scientists (atmospheric physicists, biologists, geologists, etc.) keep defining what is best 
for a healthy planet and ecosystem. The knowledge and perception are constantly updated, reviewed, design approaches adjusted.

Understanding the relationship of nature - architecture - man developed throughout history was possible only because of advancement in understanding both nature and architecture. Some of the early approaches might seem naïve, or romantic, but they are the witness of time and probably the best attempt of its time. That is why the name of the approach itself in literature, journals, magazine titles varies: organic, bioclimatic, sustainable, green, restorative, regenerative, planet-oriented etc., they are current states of knowledge or willingness to use certain methods and techniques to design architecture that builds a positive (retrofit brownfields, capture pollution, reduce urban heat island, enhances biodiversity) and harmonic (enters in a symbiotic relation with living systems for example hosting bird nests, design according to topography) relationship with the planet. Planet-oriented architecture looks from the holistic point of view to provide the best living condition for humans and to restore and regenerate the ecosystem. In this framework all beings are on equal rights, and providing safe and healthy shelter for people cannot have a negative impact on other beings.

\section{Organic architecture}

Organic architecture as a movement was declared at the British architects meeting in 1939 [12] by Frank Lloyd Wright (1867-1959), although some previous thoughts were included in Burckhardt's (1818-1897) early writings [13], Wright [14] and Sullivan (1856-1924) texts selection [15]. Nature ${ }^{1}$ as the environment in which architecture is built was crucial to Frank Lloyd Wright's writings and architecture. In one of his first critical texts [16], written in the same period he was designing Prairie-style houses, in the cause of architecture he advised:

A building should appear to grow easily from its site and be shaped to harmonize with the surroundings if Nature is manifest here, and if not try to make it as quiet, substantial, and organic She would have been the opportunity Hers.

Later in The Natural House, a book dedicated to organic architecture built in harmony with the site by the use of local materials (though it did not reject steel as a material that allows larger spans and visual connection to the outdoors), he wrote:

The Usonian house then aims to be a natural performance, once that is integral to the site; integral to the environment; integral to the life of the inhabitants.

This quote might be a good reference for architecture performance much later, at the beginning of the $21^{\text {st }}$ century, defined by Michael Hensel (1965-), German architect and scholar [17]. He argues that the measure of the sustainability of architecture lies in its agency ${ }^{2}$ which is expressed in four domains: local communities, the local physical environment, spatial and material organization complex. Bruno Latour (1947-), a French sociologist, would

1 Wright would always write Nature with a capital 'N'. Asked by Mike Wallace in 1957 about his religious vision he answered: 'my church, I put a capital $\mathrm{N}$ on Nature and go there.'

2 'In very general terms, an agent is a being with the capacity to act, and 'agency' denotes the exercise or manifestation of this capacity.' in Stanford Encyclopaedia of Philosophy 
comment that architecture is one of the elements of a complex network of connection [18]. The Usonian Houses exercise a performative approach - for example, the Robie House in Illinois is ventilated naturally so that it does not use grid energy for this purpose; the glazing on its southern facade was maximized to increase solar gains and daylight autonomy, and limited in the north to increase energy efficiency. Finally cantilever roof overhang looks to minimise overheating in summer. In Herbert and Katherine Jacobs' Second House in Wisconsin, known as Solar Hemicycle, the north rear wall was protected by an earth berm which protected from heat loss, a superior part of the wall was exposed to allow natural cross-ventilation, high interior walls were made of stone that stores heat. South-facing crescent-like facades allowed sun rays penetration during the winter and protected by sun-shades in the hottest summer months. The Wright design could be considered a great example of a passive house and maybe a prototype of a nearly zero energy building. The performance and relation with the sun, wind, land were shaping the design of houses.

Marion Mahony Griffin (1871-1961) was Wright's apprentice and ran the studio during his travels. In a more conventionally organized office, she would have held the title of 'head designer or associate' [19]. She was one of the pioneers of the organic movement in architecture and collaborated on prairie houses. Later she teamed up with her husband and opened a studio of their own. Although she did not publish all her texts, as a digitized manuscript, these are available under the title: The Magic Of America [20].

All the evidence of historic civilizations among men prior to the Romans exhibit also the second essential - subordination to nature and indicate something in these civilizations that we lack-a closer relationship of man to nature. [...] Feudal castles appear to grow out of the jagged rocks of Europe. The mud houses of the African deserts and the storied adobe cities of the Pueblo Indians in America are as distinctly part and parcel of a homogeneous nature $[\ldots]$

Marion Mahony Griffin points out that pre-civilized communities lived in a closer relation to nature. Civilization brought about the possibilities and progress which looked for more universal and large scale solutions. The ancient tribes used resources that were available in the closest neighbourhood. Today it could be defined as operating within planetary boundaries, biocapacity or within circular economy rules. The pre-Anthropocene societies, where the Anthropocene is understood as a geological era, predominantly due to their size, sacredness and technical skills, were unable to impact the environment permanently.

In Italy, in 1945, just after the II World War had finished, Bruno Zevi (1918-2000) and with Cinco Calparina and Silvio Radiconcini established Associazione per l'architettura organica. The organization looked for a new agenda, in opposition to rationalism, advocating for non-monumental architecture, that allowed fulfilling the spiritual and psychological needs of the society. It was a political, not an aesthetic movement. Maria Clara Ghia [21] points out three principles that it was built on: the first was political justice and freedom; the second, the need for a constitution that secures equality; and the third, to guarantee full social liberties. If any formal direction could be defined it must have been in opposition to rationalism and geometrism. Zevi explained the idea at the First National Congress of Associazione per l'architettura organica: 
Organic architecture is a functional architecture, respecting not only the techniques and purposes as the building but also the psychology of users. Everything else is a gratuitous comment, you can go and update yourself [22].

The definition of organic of Zevi was vast and would rather constitute opposition to rational or de facto fascist architecture of the past. The relation with Nature or environment was not in its focus. The organic architecture of Zevi would take a human-centred position, not planet-centered. The term that Zevi uses is misleading, it is associated with living organisms not with the physical, spatial or psychological aspect of a space. In his book Toward Organic Architecture he wrote:

Architecture is organic when the spatial arrangement of a room, house, and city is planned for human happiness, material, psychological, and spiritual. The organic is based therefore on a social idea and not on a figurative idea. We can only call architecture organic when it aims at being human before it is humanist.

Such understanding of an organic approach does not look for relation with the Planet. It looks for the essence or properties of space. Similarly Wright used the expression the idea of natural materials based on its nature, where nature should be understood as properties not their source [23]-[25].

Last but not least there is the Finnish architect and designer duo, Alvar (1898-1876) and Aino Aalto (1894-1949). The organic aspect of their work could be analysed on two levels: formal (shapes) and in relation to nature. Aalto's shapes both in architecture and design express a continuity and softness of lines and surfaces. Just to mention the Church of the Assumption of Mary in Riola di Vergato (Bologna, Italy), Baker House in Cambridge (USA), or Savoy Vase. Their relation to nature was much more complex and should be understood in the context of Finland, a country located in between forest and lakes, on the periphery of Europe. Ari Hynenen observes Kirmo Mikkola's [26] statement that although Alvar Aalto never wrote a book which formulates the design principles, it could nevertheless be observed in his architecture, text, lectures or speeches. One of the elements that could be found in Aalto's architecture is biophilia - being surrounded with Nature - plants and animals, depending on the weather and seasons and more. This unique relationship with nature was popularized by Edward O. Wilson (1929-), American biologist, who in 1984 described these characteristics as: 'an innate tendency to focus on life and lifelike processes, urge to affiliate with other forms of life' [27] suggesting that since the very beginning humans have been in a strong, and inevitable, relation with Nature. In Aalto's work, it could be observed in the Town Hall of Säynätsalo (Finland), where the building is 'hidden' in the forest, blended in the rocky bed with multiple terraces, and provides a peaceful and intimate atmosphere.

Frank Lloyd Wright's person is key in the conversation about organic architecture. Until today architects are referring to his work and approach. A very wide framework drawn by Wright allows fitting projects of distant approaches or principles. Nevertheless, sometimes his ideas are reduced to pure formalistic and aesthetic decisions. There is much misunderstanding and confusion, for example, materials used by Wright should express its nature, not to be natural. The nature of materials is understood as their physical properties [23], [28]. ${ }^{3}$ In Fallingwater House (Pennsylvania, USA), one can find not only wood and stone, as probably

3 It opens a wide field to interpretation and misinterpretation. 
expected but also concrete and steel. Kenneth Frampton (1930-), an American architecture critic, summarized organic architecture:

Although it always escaped any precise definition, seems to have eventually meant for Wright the economic creation of built form and space in accordance with the latest principles of nature as these may be revealed through the application of the reinforced-concrete construction [29].

Today architects continue using 'organic architecture' with the same wide meaning. Carlos Martí Arís in 'La cimbra y el arco' observes that 'organicism in reality was a modality of functionalism' [30]. It could be interpreted starting from non-straight forms, through materials, to the relation with nature. The perspective can include architects starting from Wright, through Hugo Haering, Hans Scharoun, Paolo Soleri, Arthur Kieseler or more contemporary Javier Senosiain, Roznana Montiel, Hiroshi Sambuichi, Zaha Hadid or MAD Architects. Organic architecture should be understood as a period that allows to discover the importance of the relationship of architecture, nature and man that led to a planet-oriented approach. There are some elements, such as visual connection to Nature or attempt to blend with the landscape through the use of local materials.

\section{Vernacular architecture}

As an opposition to the International Style [31] announced at the exhibition Modern Architecture in MoMA of New York or standardization of architecture or rejection of local materials [32] several architects proposed to look at the past and the region. Among them the voice of the co-author of the catalogue of the exhibition: Lewis Mumford (1895-1990), the architecture historian and critic Sibyl Moholy-Nagy (1903-1971), the Egyptian architect and scholar Hassan Fathy (1900-1989) or the Moravian-born architect and writer Bernard Rudofsky (1905-1988) called for learning from the past. ${ }^{4}$

Grzegorz Rytel, a researcher from Warsaw University of Technology, points out [33] that the term vernacular architecture was used first in the mid-19 $9^{\text {th }}$ century by Gilbert Scott to define architecture that is typical for a certain region. This idea was expanded by Paul Oliver, author of the Encyclopaedia of Vernacular Architecture of the World, where he reminds that such architecture must be based on knowledge passing from generation to generation [34].

Mumford studied the relation nature - architecture - man at the beginning of the $20^{\text {th }}$ century, for example in Technics and Civilization [35]. As Lance Strate and Casey Man Kong Lum observed '[he] is concerned in concrete and practical ways with both the biological and technological habitats of the human species' [36]. His lectures at Alabama College took the form of a book [37] which maps the relations with nature and human impact.

The individual unit must always be conceived and modified in terms of the whole. This cannot be done by architects who have their nose on the drawing board, and who, in their own conceit, have no regard for the principle of neighbourliness and no interest in the surrounding works of nature and man.

4 Here the figure of Angelus Novus by Paul Klee persecuting. 
Sibyl Moholy-Nagy, architectural critic and professor of the Pratt School of Architecture, dedicated a big part of her professional career to research and map vernacular architecture of the Americas. Native Genius in Anonymous Architecture [38], an outstanding guide to locally designed architecture based on indigenous and settlers experience is the most important part of her publishing in vernacular architecture. She had also previously published several articles on the same topic in Perspecta [39]: The Yale School of Architecture Journal and Casabella [40]. In the sixties, she continued her research and writing with $A$ Study of Education for Environmental Design [41] or The Making of Non-Architects [42] to list some. She advocated for learning from the past as a strategy to design a better-performing architecture.

This folklore of building will be meaningless to those who define architecture either as pure aesthetics, expressed in Le Corbusier's poetic exclamation: "Architecture is the play of light-supreme and magnificent - on significant form"; or to those who consider it predominantly a branch of modern technology, believing that "engineering will absorb architecture" and that the architect's function can only be defined in the turgid phraseology of the technocrat: "catalysing cooperative and potential resources into realigned and realizable technology and management strategy, providing a demonstrable increase in performance increments per unit of invested resources [38].

Moholy-Nagy looked to the indigenous knowledge for its ingenuity and originality in resolving local problems, solutions which could be an alternative for industrialized and out-of-context solutions. Although Native Genius in Anonymous Architecture is much more profound and detailed than Architecture without architects ${ }^{5}$ it never received as much attention. Bernard Rudofsky's book is a catalogue to an exhibition at the MoMA in New York. The photographic essay talks about regional architectures, materials, spatial solutions or response to climate. He writes:

There is much to learn from architecture before it became an expert's art. The untutored builders in space and time-the protagonists of this show-demonstrate an admirable talent for fitting their buildings into the natural surroundings [43].

The importance of this book should be seen as triggering regionalism in architecture. ${ }^{6}$ It was not Rudofsky's first approach to this topic. He obtained a title of doctor in architecture at the University of Vienna for his research in Greece concluded in: Eine primitive Betonbauweise auf den südlichen Kykladen [Santorin], nebst dem Versuch einer Datierung derselben (A primitive type of concrete construction in the southern Cyclades. Study case Santorini) and in 1947 he curated an exhibition at MoMA: Are Clothes Modern?: An Essay on Contemporary Apparel [44], which was not an exhibition on clothes or fashion, but rather looked for regional patterns, local attributes, vernacularism. It was an exhibition of design and architecture.

The last author presented among the researchers in vernacular architecture is Hassan Fathy, the most celebrated Egyptian architect. In the movie Il ne suffit pas que Dieu soit avec les pauvres [45] he says:

\footnotetext{
5 The Rudofsky exhibition and book was an album of photographs, most of them came from the collection of tourist offices, surveys made by others or museum collections [43].

6 Though it would look for the idyllic and romantic aspect of the countryside.
} 
I'm an Arab architect who has lost every point of reference in Arab society, who has lost his arabité. I'm searching for architecture and urbanism, searching and trying to find my lost arabité.

Fathy advocated for vernacular architecture, local skills and the revival of craftsmanship. Architecture for the Poor: An Experiment in Rural Egypt [46] is a guide to holistic design in architecture based on cosmology and symbolism, modus vivendi, traditional building techniques - a strong belief in craftsmanship (he researches vaults used in Ancient Egypt), local materials and more. The text, based on his professional experience as a designer, is an antithesis to the omnipresent modernism and globalization.

There must be neither faked tradition nor fake modernity, but an architecture that will be the visible and permanent expression of the character of the community.

He reminded building industry stakeholders that local knowledge is crucial to respond to the actual problems. In the chapter "Climate and Architecture", Fathy analyses environmental conditions and traditional solutions to minimize heat radiation, temperature control or ventilation. In vernacular solutions he looks for a passive design ${ }^{7}$ scheme.

His posteriori texts such as Natural Energy and Vernacular Architecture [47] or The Mud Brick Manual: Vault and Dome Construction [48] bring more solutions based on native knowledge. Even though he promoted vernacular architecture (in the meaning of 'from the place') he worked on a project in Saudi Arabia and New Mexico ${ }^{8}$ (Muslim community at Dar al Islam) where he transplanted the ideas born in Egypt. Both locations share similar climatic characteristics and cultural background.

The vernacular studies were also undertaken by the modernist architects (practitioners) who look to expand their workshop and tools they used. In Portugal, a group of well-established architects, on the request of the government [49], travelled the country to look for popular architecture patterns. They mapped the relationship between landscape, territory, architecture and the ways of living. The efforts were concluded in the book Arquitectura Popular em Portugal [50] which is, until today, a primer for Portuguese-educated architects. Also, Lina Bo Bardi (1914-1992), an Italian-born, Brazilian-established architect, celebrated and researched popular architecture. Some of her thoughts could be found in the essay: Architettura e natura: la casa nel passaggio [51] for Domus:

Through deep evolution, the primitive instinct for protection that led man to build thatch and straw huts, cone-shaped shelters, or massive stone blocks, is again in force to define housing architecture which, although it adapted to the harsh laws of functionality and essentiality of modern architecture, they always retain the 'purity' of the spontaneous and primordial forms from which they derive. (...) We are not talking here of external appearances

7 Passive design is understood as a strategy that replaces energy obtained from the grid with natural energy sourced directly from the environment (such as solar energy or earth heat) to enhance building performance. Passive measures are based on architectural and constructive solutions, material selection, building orientation or shape.

8 Even though the locations were distant, they shared the same climate conditions, according to The Köppen climate classification and cultural background. 
or regional folklore, but of those values that as a result of the serious investigation undertaken by modern architecture against the 'false', the 'stylized' and the 'crystallized'.

At that time there was no vision of planetary interdependencies, designing for local (vernacular) conditions was the way to an adequate response to the site, weather patterns, available material, and the way of living. Only more recent studies look for a more complete picture, and includes more, if not all the biotic and abiotic actors. For example Natalia Przesmycka [52] embraces the history, local climatic conditions, materials and resources, geographical conditions and cultural influences in search for a more holistic picture of the architectural vernacular production in Iceland.

\section{Tropical and bioclimatic architecture}

Once the idea of global architecture disseminated globally local versions of modernism started to appear in 'tropics'. In the early '50 Le Corbusier (1887-1965), Jane Drew (1911-1996) and Maxwell Fry (1899-1987) were invited to Chandigarh to continue the plan for a new capital of an Indian state Punjab, a few years later the initial idea for The National Assembly Building in Bangladesh was conceptually conceived by Louis Khan, Pancho Guedes constructed housing projects in Maputo (interestingly Guedes embraced folk but not vernacular ${ }^{10}$ architecture of Mozambique), 1957 Lucio Costa won a national competition to design Brasilia, in the early sixties in México Pedro Ramírez Vázquez designed Museo de Antropología. The academia did not stay behind and in 1955 the Architectural Association (AA) School of Architecture launched The Department of Tropical Architecture directed by Maxwell Fry and James Cubitt. The topic was first illustrated in Architectural Review [54] that was dedicated to the West African ${ }^{11}$ educational buildings (where Fry and Drew were consultants already in the mid-1940s). Their field and consulting experience concluded in the book Tropical Architecture in the Humid Zone [55] that describes climatic characteristics and their impact on architectural design, health, and hygiene in illustration, map, diagrams and tables. The book is written as a practical guide, based on their experience and observation, for fellow architects. Almost ten years later, the same duo wrote Tropical architecture in the dry and humid zones [56] expanding the knowledge to other climatic zones. Anyway, the architecture was treated as an artifact, the solutions proposed were technical or technological and were imposing the European way of living and being. Otto Königsberger, an architect experienced in south India ${ }^{12}$, who took over the chair of The Department of Tropical Architecture, published a short essay on tropical architecture in 1965 [57], which serves

9 Although the idea could be tracked much earlier - already in 1810, Thomas Williamson in The East India Vade Mecum [53] criticized a lack of adaptation to climate and copying architecture: 'by no means consistent with common sense . . and displaying a total ignorance of the most simple of nature's laws' pp.7-8. Also in the twenties of the XIX, with the flow of Jews and Jewish architects from Germany to Mandatory Palestine, Bauhaus architecture was transplanted. Though the formal style was not adjusted to the local climate, the cultural context was by the newcomers and was a continuation of the European diaspora life.

10 Here folk is understood as an expression of certain aesthetics.

11 From the forties West Africa was a field of intensive research and experiments. Next to Drew and Frey, Labelle Prussin was there surveying indigenous architecture in northern Ghana, Paul Oliver starts his research on vernacular architecture also in Ghana, Accra and Lagos are experiencing a great import of socialist architecture and architects.

12 He commenced working for the Mysore State (a state that was granted a large autonomy from the British Empire) for westernized Hindi people and continued in the independent India. 
as a reference to this day. Although it was Manual of tropical housing and building: climatic design [58] that has been widely published and distributed. In the introduction, the author explains that he addresses the book to the students and as a reference for practitioners, and finally as an aid for their clients. The text is a detailed technical guide to climate, vegetation, it introduces topics such as thermal comfort, ventilation schemes etc. The authors did not pay much attention to vernacular architecture. The sub-chapters on traditional architecture for selected climates are short, the examples are cursorily explained without diagrams showing for example air-flow, it is seen as a curiosity not as a problem-solving reference. The origins of the bioclimatic design are rooted in the International Style, which rejected local knowledge. Such architecture seems to be another tool in globalization and colonization strategy.

The first publication which tried to explain the physics behind the relation nature - architecture was Design with Climate by Victor (1910-1970) and Aladar Olgyay (1910-1963). A detailed guide [59] mapped the influence of the environment on architecture. Illustrated with numerous diagrams, sketches, graphs and photographs, it has been a base for a bioclimatic design for decades. It explains the influences of the climate, wind, humidity, topography on human performance, well-being and health. The modern-day computer simulations are rooted in the daylight or air flow studies presented in the book [60]. Limited bibliographical references prove its pioneering role. Before Olgyay published several articles and books on the impact of the environment to architecture: The Temperate House in 1951, followed by Bioclimatic Approach to Architecture and Solar Control and Orientation to Meet Bioclimatic Requirements and Application of climate data house design in 1954, and Solar Control and Shading Device in 1957.

The works of Drew, Olgyay and Königsberger echo into the research of Susanne Roaf, Professor of Architectural Engineering at Heriot-Watt University in Edinburgh. She is best known for strategies for adaptation of buildings for climate change [61] and verifying vernacular architecture sustainable solutions against the contemporary computer energy modelling [62]. Fionn Stevenson develops the same field through the lens of building performance evaluation, examining performance [63] in relation to energy efficiency [64], occupant satisfaction [65] or carbon emissions [66]. Their work brings an engineering aspect of contemporary architecture in relation to nature that could be measured and optimized.

$[I] n$ the warming climate [.. it] reminded us not to follow the stereotypical thinking of 'conventional wisdom' but to re-think each design decision clearly for ourselves and remind us that the sustainability stool has three legs, and if you lose one, the stool falls. [67]

Last but not least, the works of the already mentioned pioneers from the ' $50 \mathrm{~s}$ and ' $60 \mathrm{~s}$ play an important role in understanding modern and contemporary sustainable architecture and its stakeholders.

Engineering companies (ARUP, Buro Happold, The Smith Group etc.), innumerate certification systems (LEED, WELL, Passive House, BREEAM etc.), high-performing architecture, digital tools (like Ladybug, Energy+, Ecotec) benefit from their work. Tom Eichbalm from the Smith Group chooses an orientation of The Chesapeake Bay Foundation based on the classes taken from Olgyay's Design with Climate. The thermal performance evaluation methods described by Olgyay, for example, are in use until today and were translated as digital tools for computer simulation. As David Leatherbarrow and Richard Wesley, scholars from the University of Pennsylvania School of Design, point out, Olgyay's 'research and publications laid the foundation for much of the building simulation software in use today' [68]. For example Ladybug Tools, 
one of the most popular set of tools for daylight and energy visualization and simulation, uses Olgyay's work as a reference [69].

\section{Planet-oriented architecture}

Design with Nature [70], alongside the already mentioned Silent Spring, constitutes the backbone of planet-oriented thinking in the sixties. These two texts helped the activist to transform the enthusiasm into policies such as the National Environmental Policy Act in 1970 and the Clean Water Act in 1972. Ian McHarg (1920-2001) was a landscape architect, the knowledge he gained at Harvard University encompassed both architectural theory, biology and environmental science. Such education allowed him to write a book from a wider perspective: a planetary, holistic vision, where city and urbanization are understood as a continuation of natural landscapes. All the elements of environment, biotic and abiotic, form the context for architectural design. An attempt to design against it would, sooner or later, be a failure. The text brings detailed solutions and design strategies, speculation, and thoughts on the relation nature - architecture - humans. The work of McHarg is continued at The McHarg Center at the University of Pennsylvania. Fifty years after the premiere of the first edition the university published an up-to-date sibling [71].

Buckminster Fuller (1885-1983), one of the brightest minds of generation, designer and author of several books which have shaped design and architecture, in Operating Manual for Spaceship Earth [72] draws a picture of the Earth as an element of the solar system, an organism ${ }^{13}$ that functions based on physical and chemical processes that keep regenerating and allow the appearance of life. According to Fuller, the Earth is a spaceship that flies through space and has limited resources which, once extracted, cannot be restored. The book was published just three years before the first issue of The Whole Earth Catalog ${ }^{14}$, a magazine which advocated self-sufficiency, permaculture, ecology, and holism. The first colour image of Earth, taken in 1967 by the ATS-3 satellite, was used as the cover image of the first edition of Whole Earth Catalog. The catalogue was a part of a larger counterculture movement. In 1956 Paolo Soleri (1919-2013), Wright's apprentice started the construction of the Arcosanti, a bottom-up, community-driven development in Phoenix which looked to integrate architecture and ecology in a holistic way. In Arcology he observes [75]:

We interpose between the scattered plenitude of nature (remember its unhuman module of space-time) and the dense introspective plenitude of man, the platitude of our handiwork, the artificial. What we need is that in-between structural systems by which nature itself is filtered and welded in forms more apt to carry the extreme valence of contemporary man, an ecology made of nature and man, framed in an architectural system.

However, some recent critiques on Paolo and Colly Soleri indicate that the project was far from being sustainable [76], due to its location, incorrect solar orientation of buildings or water management [77]. Soleri, alongside Drop City, is the most known building of the hippie movement of the sixties. Auto-sustainable communities were growing all around the world,

13 The idea grows along with the General System Theory coined by Ludwig von Bertalanffy in the late 1930's and concluded in Ludwig von Bertalanffy, General System Theory: Foundations, Development, Applications, 1969. [73]

14 The Catalogue edited by Stewart Brandt was published regularly between 1968 and 1971, later in an extraordinary matter. [74] 
questioning capitalism and its production such as architecture and design. The architecture of such development has strong roots in cosmology, close relation with nature, and almost primitive living. In that context, the movement of Earthships commenced by Michael Reynolds (1945-) in the seventies must be mentioned. Reynolds, an American architect based in the hot and arid New Mexico, developed one of the first off-grid, self-sustainable houses, that used passive strategies, minimized waste, reused materials for construction or harvest and stored water on-site. His idea has spread in numerous locations, in different climates and geographical conditions.

The issue of the planet-oriented approach transcendent to all disciplines also to industrial design, which was an emerging discipline in the sixties and seventies. There is no doubt that Design for the Real World [78] by Victor Papanek (1923-1998) set the discussion on mass-production, the necessity of design, tools, topics, client-designer relations for several decades, and strongly influenced contemporary architectural thought. Papanek looked for the essence of design and the necessity of creation as an initial point in a discussion about sustainability and what is today called 'degrowth' 15 .

Papanek was a part of a larger informal group formed by Rachel Carson, Buckminster Fuller, and Jane Jacobs. The group advocated for holistic design and looking for the essence of the problem, not to redesign or to fix the broken system. Jacobs (1916-2006), who was a social activist and journalist, strongly influenced the contemporary understanding of urban design and architecture. She looked for 'living neighbourhoods and street ballet' as a measure of a healthy city. In The Death and Life of Great American Cities [79] she writes:

Human beings are, of course, a part of nature, as much so as grizzly bears or bees or whales or sorghum cane. The cities of human beings are as natural, being a product of one form of nature, as the colonies of prairie dogs or the beds of oysters.

She looked to embrace nature and include all the beings, in the posthumanism spirit, as an equal element of the system. A city is a natural extension of the landscape, architecture is the ecosystem.

The idea of Planet-Oriented Design has become an important element of scientific research of today. For example European scholars organized around the idea of restorative and regenerative design have amplified the traditional knowledge production to building operation and maintenance [80], technology [81] and economy of scale looking for a holistic view and the entire lifecycle of a project. The restorative approach looks to reverse the harm and damage made by humans or caused by human activity on the natural systems. The concept of regeneration originated in a living systems model of Steve Larrick, American researcher [82] Bill Reed, architect, lecturer and author, introduced the idea of regeneration to architecture [83]. In that paradigm, the built environment has a positive impact on the ecosystem, e.g. instead of minimizing the heat island effect it ensures outdoor environmental comfort. The regenerative design looks to increase planetary capacity, empower all species, and enhance the ecosystem. The regenerative approach aims to create a more resilient and inclusive future.

The scientist and architects tried to expand their agency by working with Non-Governmental Organizations and publishing manuals for non-architects that look to help the local communities to build in an equilibrated and sustainable way. In the early 1980s, Secretaria de Assentamientos Humanos y Obras Públicas de México published a DIY (Do It Yourself)

15 A topic widely explored during the last Triennale of Architecture in Oslo in 2019. 
manual [84] written by Johan van Lengen which explains the variety of climates and the corresponding architectural solutions.

\section{Summary}

The first analysed movement - organic architecture - should be seen as a moment of establishing a new relationship between industrialization, a modernizing world and Nature, and as an origin of the posterior movements. Even though works of Frank Lloyd Wright or Alvaro and Aino Aalto should be seen as a modality of functionalism, they explored the relationship between man and architecture in the early $20^{\text {th }}$ century. Organic architecture neither looked to protect nor regenerate Nature, it was an initial moment of understanding such a complex relationship. Vernacular Architecture should be seen as a source of knowledge based on the tradition and experience. There is no doubt that Sybil Moholy-Nagy and Hassan Fathy have seen traditional architecture as a source of knowledge to design according to the climate and with the use of local materials and skills. The care for the neighbourhood (Nature) has been a part of an agenda of vernacular architecture and traditional societies. Tropical and bioclimatic movements which looked to adapt architectural patterns developed in Europe and the USA brought a set of tools allowing measure performance of a building. Works of Otto H. Königsberger and Victor Olgyay on building performance allowed the establishment of a new discipline based on simulation which has been developed to the present day. Finally, the planet-oriented should be seen as the latest embodiment of the environmental-sensitive movement, one that embraces ideas of restoration and regeneration as the principal axis of the agenda. This framework allows observing the ecosystem from inside and outside. Architecture and the built environment as parts of a larger system play an important role in the ecosystem. Hence, to contribute in a positive way to regenerate the Planet, it should follow the recommendations of IPCC Reports and the 17 Sustainable Development Goals indicated by the United Nations. Multiple attempts such as the UK Architects Declaration of Climate and Biodiversity Emergency should be considered as tangible significant steps in the right direction.

All the movements emerged from care for nature. They used different tools, used distinct frameworks, and vocabulary. Although some continuity could be observed, two parts could be distinguished: the initial one, which circles around Wright, Aalto, Mumford, and Jacobs, and is based on emotions, relations, assumptions, and second - the quantitative, which commences with tropical architecture, represented by Jane Drew or Victor Olgyay. In recent years, the second approach has been taken over and continued globally to look for the best performing, engineered architecture, both in research and practice. The vernacular approach does not fit the globalized world of the architecture of glass and steel, though it has the most potential since the solution it employs has been reviewed for many generations and in its core has regeneration and positive impact on the environment that is a part of it.

The future research might look for a deeper understanding of vernacular architecture and its relation to Nature, researching regions that have not been explored yet. Following the steps of Rudofsky to look in the existing texts (it could include non-Western scholars) or of Sibyl Moholy-Nagy making a survey to look for environmentally-conscious solutions. Additionally, the further research could trace female presence in the field. The author believes that the role of Sibyl Moholy-Nagy, Jane Drew and Susanne Roaf is underestimated. 


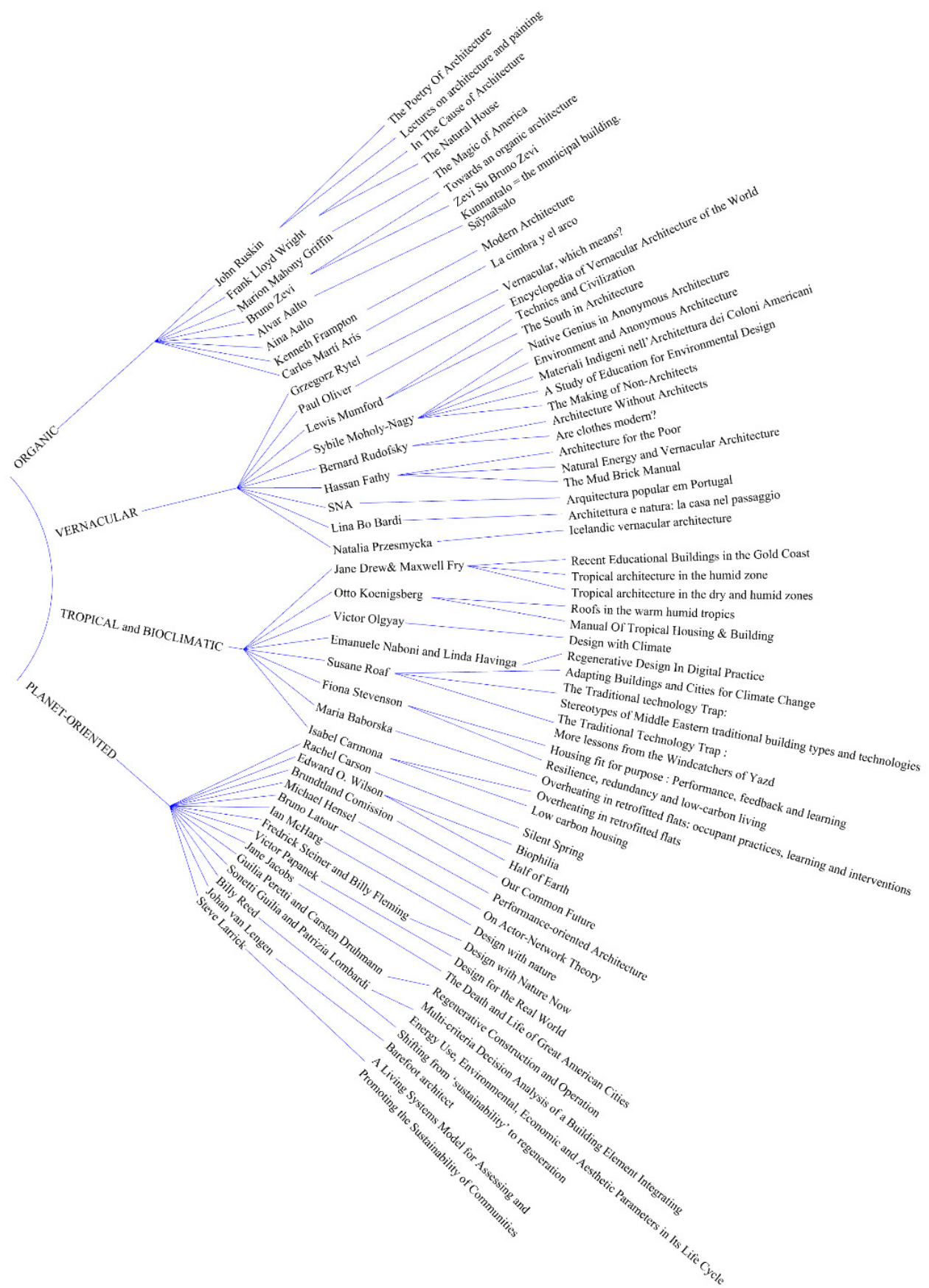

Fig. 1. Many beginnings: the thought, thinkers and actions behind the planet-oriented architecture - diagram (source: own study) 


\section{References}

[1] Ruskin J., Lectures on architecture and painting. London; New York: George Routledge \& Sons: F.P. Dutton \& Co, 1845. Available: http://catalog.hathitrust.org/api/volumes/oclc/34040212.html

[2] Rusikin J., The Poetry Of Architecture: Or, The Architecture Of The Nations Of Europe Considered In Its Association With Natural Scenery And National Character. New York: Wilen, 1923. Available: https://archive.org/details/poetryofarchitec00ruskuoft

[3] Hunt J.D., "Ruskin: The Design of Nature and the Transcription of Its Manuscript", Assemblage, no. 32, (1997), pp. 13-21. https://doi.org/10.2307/3171404

[4] Des Voeux H.A., "Fog and Smog", presented at the London Congress Meeting, Royal Institute of Public Health, London, 1905.

[5] Leopold A., Game Management. University of Wisconsin Press, 1987.

[6] Arulke A. and Sax B., "Understanding Nazi Animal Protection and the Holocaust", Anthrozoos: A Multidisciplinary Journal of The Interactions of People \& Animals, vol. 5, (Jan. 1992), pp. 6-31. https://doi.org/10.2752/089279392787011638

[7] Carson R., Silent spring. Greenwich, Conn.: Fawcett, 1962.

[8] Dewey S., "Working for the Environment: Organized Labor and the Origins of Environmentalism in the United States, 1948-1970", Environmental History, vol. 3, no. 1, (1998), pp. 45-63. https:// doi.org/10.2307/3985426

[9] Hamilton J.D., "Oil and the Macroeconomy since World War II", Journal of Political Economy, vol. 91, no. 2, (1983), pp. 228-248.

[10] Brundtland Commission, Our common future. Oxford: Oxford University Press, 1987.

[11] Shabecoff P., “Global Warming Has Begun, Expert Tells Senate.”, New York, 24-Jun-1988.

[12] Hatje Gerd., Encyclopaedia of modern architecture. London: Thames and Hudson, 1975.

[13] Burckhardt J., Geschichte der Renaissance in Italien. Stuttgart: Ebner, 1878.

[14] Wright F.L., "In the cause of architecture", Architectural Record, no. March, (1908).

[15] Sullivan L., Kindergarten Chats and Other Writings. Dover Publications, 1918.

[16] Wright F.L., The natural house. Horizon Press, 1954.

[17] Hensel M., Performance-Oriented Architecture: Rethinking Architectural Design and the Built Environment. Wiley, 2013.

[18] Latour B., "On Actor-Network Theory. A Few Clarifications, Plus More Than a Few Complications", Philosophical Literary Journal Logos, vol. 27, (2017), pp. 173-197. https://doi.org/10.22 394/0869-5377-2017-1-173-197

[19] Manson G.C., Frank Lloyd Wright to 1910 : the first Golden Age. New York a.o: Van Nostrand Reinhold1958 ib. 79., 1979.

[20] Griffin M.M., "The Magic Of America”.

[21] Ghia M., "A lightning bolt. The activity of Bruno Zevi in post-war Italy", ZARCH, (Sep. 2018), pp. 166-177. https://doi.org/10.26754/ojs_zarch/zarch.2018102939

[22] Zevi B., Zevi su Bruno Zevi. Milano: Magma, 1978.

[23] Wright F.L., "In the Cause of Architecture IV: The Meaning of Materials - Wood", The Architectural Record, vol. 62, May-1928.

[24] Wright F.L., "In the Cause of Architecture V: The Meaning of Materials - the Klin", The Architectural Record, vol. 63, Jun-1928.

[25] Wright F.L., "In the Cause of Architecture VII: The Meaning of Materials - Concrete", The Architectural Record, vol. 65, Augsut1928. 
[26] Hynynen A., “A Deep Organic Re-reading of Alvar Aalto's Design Approach”, presented at the The $6^{\text {th }}$ Annual Symposium of Architectural Research 2014 and The Annual NAAR Symposium 2014, Oulu, Finland, 2014.

[27] Wilson E.O., Biophilia. Cambridge, Mass.: Harvard Univ. Press, 2003.

[28] Wright F.L., "In the Cause of Architecture VI: The Meaning of Materials - Glass", The Architectural Record, vol. 64, Apr-1928.

[29] Frampton K., Modern Architecture: A Critical History. Thames \& Hudson, 2007.

[30] Martí Arís C., La cimbra y el arco. Barcelona: Fundación Caja de Arquitectos, 2005.

[31] Johnson P. et al., Modern architecture : international exhibition. New York: Museum of Modern Art, 1932.

[32] Le Corbusier, Towards new architecture. London: The architectural Press, 1927.

[33] Rytel G., "Vernacular, which means? Semantic remarks as side notes on the main topic of the conference", Budownictwo i Architektura, vol. 14, no. 3, (Sep. 2015). https://doi.org/10.35784/ bud-arch. 1623

[34] Oliver P., Encyclopedia of Vernacular Architecture of the World. 1997.

[35] Mumford L., Technics and Civilization. University of Chicago Press, 1934.

[36] Strate L. and Lum C. M.K., "Lewis Mumford and the ecology of technics", New Jersey Journal of Communication, vol. 8, no. 1, (2000), pp. 56-78. https://doi.org/10.1080/15456870009367379

[37] Mumford L., The South In Architecture The Dancy Lectures Alabama College 1941. Harcourt, Brace and Company, 1941. Available: https://archive.org/details/southinarchitect009074mbp/page/ n25/mode/2up/search/reproduce

[38] Moholy-Nagy S., Native Genius in Anonymous Architecture. New York: Horizon Press, 1957.

[39] Moholy-Nagy S., "Environment and Anonymous Architecture", Perspecta, vol. 3, (1955), pp. 3-77. https://doi.org/10.2307/1566829

[40] Moholy-Nagy S., "Materiali Indigeni nell'Architettura dei Coloni Americani.", Casabella, no. 204, pp. 76-82, 1955.

[41] Moholy-Nagy S., "A Study of Education for Environmental Design”, 1967.

[42] Moholy-Nagy S., "The Making of Non-Architects", Architectural Record, vol. 14, 1969.

[43] Rudofsky B., Architecture Without Architects: A Short Introduction to Non-pedigreed Architecture. 1964.

[44] Rudofsky B., Are clothes modern? : an essay on contemporary apparel. Chicago, 1947.

[45] 'Alawiyah B. and Tabit L., Il ne suffit pas que Dieu soit avec les pauvres. [لكل يدان :[توريب] انسانسان, 2006.

[46] Fathy H., Architecture for the Poor: An Experiment in Rural Egypt. 1969.

[47] Fathy H. et al., Natural Energy and Vernacular Architecture: Principles and Examples with Reference to Hot Arid Climates. United Nations University, 1986.

[48] Fathy H. and Damluji S.S., The Mud Brick Manual: Vault and Dome Construction. 1984.

[49] "Decreto-Lei n. 40 349, de 19 de Outubro de 1955",

[50] SNA, Arquitectura popular em Portugal. Lisboa: Sindicato Nacional dos Arquitectos, 1961.

[51] Bo Bardi L., "Architettura e natura: la casa nel passaggio", Domus, vol. 191, pp. 464-471, Nov-1943.

[52] Przesmycka N., "Icelandic vernacular architecture", Budownictwo i Architektura, vol. 14, no. 3, (Sep. 2015). https://doi.org/10.35784/bud-arch.1634

[53] Williamson T., The East India Vade-Mecum. Creative Media Partners, LLC, 2018. 
[54] Drew J. and Fry M., "Recent Educational Buildings in the Gold Coast", The Architectural Review, May-1953.

[55] Fry M. and Drew J., Tropical architecture in the humid zone. London: Batsford, 1956.

[56] Fry M. and Drew J., Tropical architecture in the dry and humid zones. B. T. Batsford, 1964.

[57] Koenigsberger O. H. and Lynn R., Roofs in the warm humid tropics. Published for the Architectural Association by Lund, Humphries, 1965.

[58] Koenigsberger O. H. et al., Manual Of Tropical Housing \& Building. Orient Longman Private Limited, 1975.

[59] Olgyay V. and Olgyay A., Design with climate : bioclimatic approach to architectural regionalism. Princeton: Princeton University Press, 1963.

[60] Naboni E. and Havinga L., Regenerative Design In Digital Practice. A Handbook for the Built Environment. 2019.

[61] Roaf S. and et al, Adapting Buildings and Cities for Climate Change. Taylor \& Francis, 2006.

[62] Roaf S., "The traditional technology trap: Stereotypes of Middle Eastern traditional building types and technologies", Trialog, vol. 25, (Jan. 1990), pp. 26-33.

[63] Stevenson F., Housing fit for purpose : Performance, feedback and learning. London: RIBA Publishing, 2019.

[64] Stevenson F. et al., "Resilience, redundancy and low-carbon living: co-producing individual and community learning", Building Research and Information, vol. 44, no. 7, (Aug. 2016), pp. 789-803. https://doi.org/10.1080/09613218.2016.1207371

[65] Baborska-Narożny M. et al., "Overheating in retrofitted flats: occupant practices, learning and interventions", Building Research and Information, vol. 45, no. 1-2, (Oct. 2016), pp. 40-59. https://doi.org/10.1080/09613218.2016.1226671

[66] Carmona-Andreu I. et al., "Low carbon housing: Understanding occupant guidance and training", Smart Innovation, Systems and Technologies, vol. 22, (Jan. 2013), pp. 545-554. https://doi.org/1 0.1007/978-3-642-36645-1_51

[67] Roaf S., "739: The Traditional Technology Trap (2): More lessons from the Windcatchers of Yazd", (Jun. 2020).

[68] Leatherbarrow D. and Wesley R., "Performance and style in the work of Olgyay and Olgyay", Architectural Research Quarterly, vol. 18, (Jun. 2014), pp. 167-176. https://doi.org/10.1017/ S1359135514000475

[69] Ladybug Tools, Available: https://grasshopperdocs.com/components/ladybug/bioclimaticChart.html

[70] McHarg I., Design with nature. Published for the American Museum of Natural History [by] the Natural History Press, 1969.

[71] Steiner F. and Fleming B., Design with Nature Now. Lincoln Institute of Land Policy, 2019.

[72] Fuller R.B., Operating manual for spaceship earth. 1965.

[73] von Bertalanffy L. et al., General System Theory: Foundations, Development, Applications. G. Braziller, 1968.

[74] Brand Stewart., The Next Whole Earth Catalog. Sausalito, Calif.; New York: Point ; Distributed by Random House, 1980.

[75] Soleri P., Arcology: The City in the Image of Man. MIT Press, 1973. Available:

[76] English M., “Arcosanti:Why?”, The Architects Take.

[77] Albright J., "Initial Findings. Arcosanti Oxidation Pond", Arizona Wetlands Research Foundation, 2003.

[78] Papanek V., Design for the Real World. 1971.

[79] Jacobs J., The Death and Life of Great American Cities. Vintage Books, 1992. Available: 
[80] Peretti G. and Druhmann C.K., Regenerative CONSTRUCTION AND OPERATION. COST Action CA16114 RESTORE, Working. Group Three Report: REGENERATIVE CONSTRUCTION AND OPERATION. Eurac, 2019.

[81] Sonetti G. and Lombardi P., "Multi-criteria Decision Analysis of a Building Element Integrating Energy Use, Environmental, Economic and Aesthetic Parameters in Its Life Cycle", 2020, pp. 463-477. https://doi.org/10.1007/978-3-030-23786-8_26

[82] Reed B., "Shifting from 'sustainability' to regeneration", Building Research \& Information, vol. 35, no. 6, (Nov. 2007), pp. 674-680. https://doi.org/10.1080/09613210701475753

[83] Larrick S., "A Living Systems Model for Assessing and Promoting the Sustainability of Communities.", presented at the Annual Meeting of the Community Development Society, Athens, 1997.

[84] Lengen J. van, Barefoot architect. Bolinas, Calif.; Enfield: Shelter; Publishers Group UK, 2007. 
